\title{
Fatal Convergence in the Kingdom of God: The Mountain Meadows Massacre in American History
}

\author{
SARAH BARRINGER GORDON \\ AND JAN SHIPPS
}

"O Lord, my God, receive thy spirits, it is for thy Kingdom that I do this." This was the prayer uttered by a Mormon participant in the notorious Mountain Meadows Massacre of 1857, as he fatally shot those already wounded. The massacre was an important by-product of religious change in early national life, and an infamous example of whiteon-white violence in the antebellum American west. The longer history and dynamism of religious conflict uncovered here reveals deeply related expressions of faith by Methodist migrants on the move and Mormon settlers on the ground. As members of both faiths converged at Mountain Meadows, each was determined to build the Kingdom of God on earth and each assumed that they alone were empowered by God to conquer the continent in His name. These rival versions of Kingdom-building

Sarah Barringer Gordon is Arlin M. Adams Professor of Constitutional Law and professor of history at the University of Pennsylvania. Jan Shipps is Professor Emerita of Religious Studies, Indiana University-Purdue University Indianapolis. The authors thank many friends and interlocutors for their insight and critique, including audiences at the Huntington Library, Mormon History Association, Western Historical Association, and Washington University (St. Louis). In particular, we are grateful for the assistance of Philip Barlow, Larry Coates, Debra Marsh, Lynnmarie Fancher, Richard Turley, Alison Wallner, Will Bagley, Richard Bushman, John Wigger, Ralph Gray, and Leigh Schmidt. We also thank the editors and reviewers of the fournal of the Early Republic, who have helped immeasurably, especially in helping us grapple with the more unconventional source material for the Fancher story. 
run like a seam through our story, linking the perpetrators and victims in claims of religious power and destiny. ${ }^{1}$

The story of the massacre is quickly told. By the time a wagon train led by Alexander Fancher reached Mountain Meadows in remote southern Utah in early September 1857, relations between the migrants and Mormon settlements along the trail had become difficult, in part because the Latter-day Saints refused to sell grain and other supplies, but also because suspicion colored all interactions between Mormons and the migrants. The Saints resented those who clearly despised them, yet rumbled through their new home in the Great Basin. (See Figure 1.) Their Zion, which they had first settled only a decade earlier, was both precious and vulnerable. The poverty of Mormon settlements, especially in the southern reaches of the territory, meant that the Saints lived at the edge of privation. The obvious wealth of the emigrants made them a tempting target. News of an approaching federal army, sent by President James Buchanan to subdue the upstart Territorial Governor Brigham Young, also whipped up Mormon fear and religious fervor. ${ }^{2}$

1. John D. Lee, Mormonism Unveiled: Including the Remarkable Life and Confessions of the Late Mormon Bishop (1877; repr. St. Louis, 1891), 241. For Methodist conquest of the Kingdom through westward expansion, see Theophilus Arminius (Thomas Hinde), "Account of the Rise and Progress of the Work of God in the Western Country," Methodist Magazine (Oct.-Nov. 1819), 393-96, 434-39; Jeffrey Williams, Religion and Violence in Early American Methodism: Taking the Kingdom by Force (Bloomington, IN, 2010), 106-28. On similar Mormon claims, see Richard Francaviglia, Mapmakers of the New Zion: A Cartographic History of Mormonism (Salt Lake City, UT, 2015), 95; Klaus Hansen, Quest for Empire: The Political Kingdom of God and the Council of Fifty in Mormon History (1967; Lincoln, NE, 1974), passim.

2. Ronald W. Walker, Richard E. Turley, Jr., and Glen M. Leonard, Massacre at Mountain Meadows: An American Tragedy (New York, 2008), 252; Will Bagley, Blood of the Prophets: Brigham Young and the Massacre at Mountain Meadows (Norman, OK, 2002), 171-74, 239-40; William P. MacKinnon, At Sword's Point, Part I: A Documentary History of the Utah War to 1858 (Norman, OK 2008), 317,326 . Note here that the federal government was both deeply expansionist and simultaneously operated largely "out of sight" in this story-our key actors are migrants, and for the most part not religious leaders. Instead, we focus on the social history of religion and local residents in newly settled regions. Brian Balogh, A Government Out of Sight: The Mystery of National Authority in NineteenthCentury America (New York, 2009). 


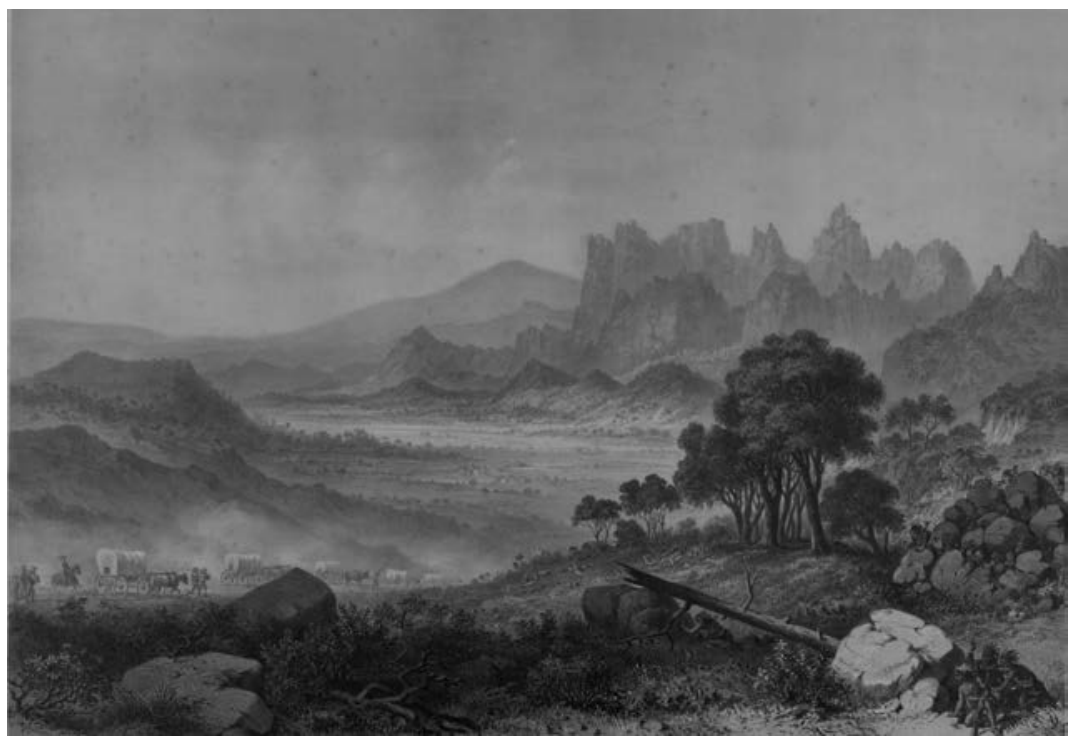

Figure 1: This lithograph of Mountain Meadows with an unsuspecting wagon train rolling through the lush and apparently peaceful valley was published two decades after the massacre, the year that John D. Lee was executed by firing squad. He died claiming that the LDS Church had made him a scapegoat, but never directly accused either Brigham Young or other Church leaders of complicity in the slaughter. Britton, Rey \& Co., Pacific Art Company of San Francisco, September 1877. Courtesy of the Library of Congress.

As a high-ranking member of the local Mormon militia, John D. Lee lashed out. The train had almost left Mormon country when it was attacked. On September 7, Lee, reputedly disguised as an Indian, led a group composed of Mormons and several Native men, killing seven and wounding more than a dozen migrants. For four days, the encircled train was besieged, primarily by Lee and other Mormons. On the morning of September 11, Mormon militiamen (represented by Lee and a companion who held a white flag of truce) told the surviving migrants that he could ensure their safe passage if they left everything behind and walked away unarmed in two columns, men in one and women and children in the other. According to Fancher family legend, Alexander Fancher had already been gravely wounded when Lee appeared among them, and he warned his fellow migrants not to trust Lee. Whatever the response was to this warning, Fancher did not survive the day: While the columns of 
migrants moved across the meadows, Mormons shot the men; the women and all but the youngest children were ambushed and killed. The death toll was 120, making Mountain Meadows the bloodiest massacre of the westward migration to date. ${ }^{3}$

Behind this gruesome story lies a complex cocktail of religion, violence, and patriarchy, tangled up with westward expansion and the ongoing construction of an American empire. To tell this story means connecting the threads that met at Mountain Meadows in 1857. Putting flesh on the bones, moreover, entails nailing down the many ways that restless and mobile Mormons and Methodists shared a central (but mutually exclusive) mission to establish Zion in America. Accepting religion as a central theme allows us to situate Mountain Meadows more firmly in American history. In that sense, we focus on the similarities between Methodists and Mormons in the early nineteenth century, especially their shared goal of migration in the interest of conquest and the establishment of the Kingdom of God. In this endeavor, multiple avenues of historical investigation yield results that integrate religious history with familial, racial, and political histories in new ways.

There were some 200 victims and participants at Mountain Meadows, led by two imposing and powerful men whose fates converged there. The interwoven lives and deaths of Alexander Fancher and John D. Lee demonstrate the power of religious identity and familial patriarchy in distinctly American iterations. We trace their lives to this point, and probe the sources and meaning of their conflict. Mountain Meadows had deep roots in the early republic, Indian wars, westward migration, the expansion of slavery, and especially in the role of religion in all these movements. These historical currents traveled alongside wagon trains, sustaining and increasing the power of those who led them. Fancher and

3. Burr Fancher, Captain Alexander Fancher: Adventurer, Drover, Wagon Master and Victim of the Mountain Meadows Massacre (Portland, OR, 2006), 111. Fancher, his family, and most of the victims were Methodists. There may well have been a smattering of Baptists among the slain. And there are a few about whom we know almost nothing. For purposes of this article, however, lack of perfect uniformity among the victims is not key. Rather, Fancher's Methodism and his leadership of the train meant that his kinfolk and other migrants understood their religion was the modal faith as they journeyed on the trail and huddled within the encircled wagons. 
Lee grew in stature across the early nineteenth century as they embraced patriarchy, violence, and migration in the name of their respective faiths. ${ }^{4}$

In key ways, this article is also an effort to recover what has been lost to the historical record. Alexander Fancher was murdered at Mountain Meadows. Records (as well as lives) were stolen that day. To tell his story, therefore, requires pushing past an imposed silence. In this work, primary documents do not align neatly underneath the text. What we recover is more collage than portrait. But we have been able to situate Fancher in his family, religious community, geographic migrations, and even military experience. As we searched, we were struck by how much Fancher and Lee shared already when they met at Mountain Meadows. Thus Lee's life helps illuminate Fancher's, giving texture to both men. The pairing of traditional archival sources for Lee with the more challenging source material on Fancher allows us to mine each for insight into the other. Equally important, fine historical scholarship, particularly in the field of American religion, grounds our work on the knife edge of religion and violence. The tale that follows resurrects a partial image of Fancher, grounded in both formal historical inquiry and less formal family histories and survivors' memories. In some senses, this material challenges our sense of the limits of historical inquiry. Yet not to listen to

4. While we use John D. Lee and Alexander Fancher here to explore the many contemporary meanings and sources of the massacre, others also played significant roles. Among the Mormons, Isaac Haight and William Dane were deeply involved, for example. Walker et al., Massacre at Mountain Meadows, 144, 174-79; Bagley, Blood of the Prophets, 156-57. Alexander Fancher is the single most recoverable figure among the victims, whose histories were all but entirely extinguished by their murders. For an extended treatment of the relationship between religion and violence, and the argument that modern secularists since the late eighteenth century have both isolated and blamed religious communities for the unparalleled bloodshed of an industrializing world, see Karen Armstrong, Fields of Blood: Religion and the History of Violence (New York, 2014). On the ubiquity of religious understandings of violent conflict from the earliest Anglo American settlements in North America, see Susan Juster, Sacred Violence in Early America (Philadelphia, 2016). In our view, bringing religion back in to the analysis of violence in the early West has the potential to deepen and qualify the work of historians who have made violence their central focus; e.g., Ned Blackhawk, Violence Over the Land: Indians and Empires in the Early American West (Cambridge, MA, 2006); Richard Maxwell Brown, № Duty to Retreat: Violence and Values in American History and Society (Norman, OK, 1994). 
these voices would be to retreat from a story that ended with an attempt to remove all evidence of the victims. Situating Fancher and Lee in broader American history, moreover, gives us a more balanced and believable account of Mountain Meadows. In place of ahistorical theories of the psychology of violence, or targeting Mormonism as a uniquely "violent faith," we argue that the many similarities and shared experiences between Fancher and Lee (and Methodists and Mormons), generate new insight into the Mountain Meadows massacre. ${ }^{5}$

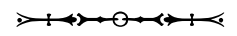

The Mountain Meadows Massacre became a pivot point in antebellum history. It etched a divide in the soil and in lives marked by decades of religious and physical migration and conflict, illustrating the potential for violence in a period of intense expansions, both geographic and religious. For many early national and antebellum Americans, their faith was everywhere, like the air around them. But when religion is everywhere, it can seem to be nowhere. Consequently, inattention to religion has become a general problem for students of westward migration and settlement. Looking closely at religious experience reveals that faith often guided behavior and interpretation so powerfully that historians who ignore or elide faith risk missing the real story. This problem is particularly acute in the historiography of the West, Mormon history included. ${ }^{6}$

We are not the first to notice the oversight; in 1953, David Brion Davis observed the "curious fact that the vast literature on Mormonism tends to treat the subject as everything but a religion." Thirty years later, Martin Marty noted briefly that the Mountain Meadows Massacre came as close to a "holy war" as anything in American history. Even though work on Mountain Meadows has expanded, these basic insights are still relevant. Moreover, the religious practices and beliefs of the Methodist victims have been overlooked almost completely. The connections

5. For the psychology of violence, see Walker et al., Massacre at Mountain Meadows, xiv, 127-28; for the charge that the church was responsible for the massacre, see Bagley, Blood of the Prophets, 23-54, and passim, and Jon Krakauer, Under the Banner of Heaven: A Story of Violent Faith (New York, 2003).

6. Jon Butler, "Jack in the Box Faith: The Religion Problem in Modern American History," fournal of American History 90 (Mar. 2004), 1357-78; Philip Goff, "Religion and the American West," in A Companion to the American West, ed. William Deverell (Malden, MA, 2004), 286-302. 
between belief and empire in antebellum America can productively be explored through the example of the two men who led each side of the fatal convergence. Their lives and experience add layers of meaning to the massacre and its place in history. ${ }^{7}$

Across their mobile lives, Fancher, Lee, and their families surged westward, bringing with them renegotiated and popular versions of white male power. Unlike some other millenarians, neither Methodists nor Mormons "waited for Jesus in the clouds." Theirs were practical, aggressive, and profoundly physical programs of building on earth. The citizens of Zion in both traditions were perfectionists, dedicated to progress, holiness, and scriptural literalism. Nineteenth-century Mormons boasted that they were a "peculiar people," by which they meant they were zealous, communally minded, and misunderstood by the rest of the world. Although they were about twenty years further down the road to respectability than Mormons, Methodists, too, maintained they were "distinctive," having endured enough persecution and opposition to learn that they (like Mormons) paid a price for doing the Lord's work. In this sense, being set apart from other spiritual communities added strength to those with the fortitude to be first on the ground, making migration a spiritual as well as a personal exercise in self-improvement. The bonanza generally went to the first to arrive, whether it be in Utah or California. ${ }^{8}$

In 1857, "Captain" Fancher was forty-five years old and seasoned in the ways of American expansion, an exemplar of the mobility and ambition of self-making white men in antebellum America. Like the Mormons who killed him, Fancher had started life elsewhere. He was born in 1812 at

7. David Brion Davis, "The New England Origins of Mormonism," New England Quarterly 26 (June 1953), 147-68; Martin E. Marty, Pilgrims in Their Own Land: 500 Years of Religion in America (Boston, 1984), 207; Ferenc M. Szasz and Margaret Connell Szasz, "Religion and Spirituality," in The Oxford History of the American West, ed. Clyde A. Milner, II, et al. (New York, 1994), 359-91.

8. Revelation 1: 7 (King James Version). On peculiarity and Mormons, see https://www.lds.org/scriptures/tg/peculiar-people; Spencer Fluhman, "A Peculiar People": Anti-Mormonism and the Making of Religion in Nineteenth-Century America (Chapel Hill, NC, 2012). On Methodists' distinctiveness, see David Hempton, Methodism: Empire of the Spirit (New Haven, CT, 2005), 82, 153. 
Sinking Cane Hollow, in central Tennessee. According to one family legend, the Fanchers were among the seventeenth-century wave of English Puritans who sailed to North America, with records going back to 1643 in New Haven. Another branch of the family claims that the Fanchers were Huguenots, French Protestants whose ancestors migrated primarily to the southern colonies in the seventeenth century as they fled Catholic persecution. By the early nineteenth century, many Huguenot descendants had concentrated in the Appalachian regions of Tennessee and Kentucky, and as far west as Illinois and Missouri. ${ }^{9}$

Like many others on the shifting western periphery of the new United States, whether Huguenot or British in origin, the Fanchers became Methodists sometime after the Revolution, participating in one of the most remarkable feats of evangelism in American history. As the religion scholar Charles Cohen described the innovative tradition in American religion, "the continuing movement of population beyond organized churches provided sufficient fuel to fire long-burning spiritual conflagrations." In the late eighteenth and early nineteenth centuries, no group could match the flint-eyed Methodist circuit riders for spiritual intensity and tenacious revival-rousing. In Tennessee alone, membership doubled in the year before Alexander Fancher's birth, especially in the central region that encompassed Sinking Cane. A fearsome earthquake and then violent tremors along the New Madrid fault, as well as the appearance of the aurora borealis and Haley's Comet, all brought portents of the end

9. The honorific "captain" was often bestowed on the leader of a wagon train. Fancher and his fellow emigrants claimed they had a right to pasture their cattle on "Uncle Sam's grass" along the trail, even though Mormons claimed to own the land. Bagley, Blood of the Prophets, 100-102. On the nationwide embrace of westward expansion as key to national survival as well as self-interest, see Balogh, $A$ Government Out of Sight, 53-111. Terry N. Fancher, "Who are the Fancher's?," http://tfancher.tripod.com/fancher.htm; http://www.mindspring.com/ fancher/ index.htm; Beverley Githens, "The Fancher Family: A Part of Our History," White River Valley Historical Quarterly 1 (Winter 1963), https://thelibrary.org/ lochist/periodicals/wrv/v1/N10/W63f.htm; Fancher, Alexander Fancher, xiii-xix, 35; David Hackett Fisher, Albion's Seed: Four British Folkways in America (New York, 1989), 605-782; Jon Butler, The Huguenots in America: A Refugee People in New World Society (Cambridge, MA, 1983); John H. Wigger, "Fighting Bees: Methodist Itinerants and the Dynamics of Methodist Growth, 1770-1820," in Methodism and the Shaping of American Culture, ed. John H. Wigger and Nathan O. Hatch (Nashville, TN, 2001), 87-134. 
of time to the region and converts to the tents and firesides of the Methodists. ${ }^{10}$

The early years of John D. Lee, Fancher's nemesis at Mountain Meadows, illustrate the overlap as well as the tension between Mormon and Methodist. Lee was born in 1812 in Kaskaskia, Illinois, the same year as Fancher, the first of many parallels between the two men. Both were born into newly settled regions along the northern edge of the old Southwest. Lee's parents, like Fancher's, had moved, in Lee's case to the far southern reaches of Illinois Territory. Lee's parents, primarily through his mother's family, were wealthier than the Fanchers. Yet Lee's life was marked early by violence and loss. His mother's first husband was murdered in 1804, and his mother gravely injured by the murderer. Her second husband, Lee's father, became a drunkard as his wife's health declined.

Lee's mother died in 1815; he was placed in the care of a "negro woman" for the next four years. Although we have no record of her name or status, it is likely that this nurse was a slave, given that his mother owned at least one other (a man named Barton that Lee recognized decades later, and described casually as one of her slaves). Certainly, Lee understood slavery: After leaving this kind woman to live with his aunt, "a regular spitfire," he complained that he was beaten almost daily_"treated worse than an African slave." Yet in this time he also learned skills that would serve him well later in life. Like Fancher, Lee became an avid hunter and adventurous migrant. Lee also developed a love of fine horses, yet another characteristic he shared with Fancher. After he ran away from his abusive family, Lee worked as a mail carrier, a job that suited his restless spirit. In 1832, he volunteered as a member of the Illinois cavalry. He shared this stint in the Illinois Mounted Volunteers with Alexander Fancher: They were part of the same regiment in the Black Hawk War-most telling, both participated in the Battle of Bad Axe (also known as the Massacre of Bad Axe). ${ }^{11}$

10. Charles L. Cohen, "The Colonization of British North America as an Episode in the History of Christianity," Church History 72 (Sept. 2003), 567; John Abernathy Smith, Cross and Flame: Two Centuries of United Methodism in Middle Tennessee (Nashville, TN, 1984), 47-66; Walter B. Posey, The Development of Methodism in the Old Southwest: 1783-1824 (Tuscaloosa, AL, 1933).

11. Lee, Mormonism Unveiled, 38; Juanita Brooks, Fohn Doyle Lee: Zealot, Pioneer Builder, Scapegoat (Glendale, CA, 1962), 21-25. Ellen M. Whitney, ed., The Black Hawk War, 1831-1832, vol. 1, Illinois Volunteers (Springfield, IL, 
Lee came to Mormonism in the late 1830s, first by hosting informal religious services in his own home in southern Illinois. When a Methodist preacher was followed directly by a sermon from a Mormon missionary, Lee was so entranced by the latter that he swore no Methodist preacher would ever be invited back. Then he borrowed a copy of the Book of Mormon, which he read through the night in deepest grief, as he kept a death watch over the corpse of his young daughter, and said he never doubted again. ${ }^{12}$

Lee joined a new religious movement, a church founded in 1830, but one that by 1838 was already seasoned in violence and migration. In part, the church was so mobile because it seemed so different. The Saints believed that the Book of Mormon was a new scripture, which restored primitive Christianity and the possibility of building a distinctive Kingdom of God, this one modeled on ancient orders-priesthood, revelation, temple ritual, and polygamy. In other words, Methodists' certainty that they were living in sacred time and that Jesus would return to America was shared by Mormons. ${ }^{13}$

Mormons and Methodists soon became dedicated rivals in the mission field. So much vitriol was exchanged between them that many scholars have implicitly accepted their claims of radical difference. To the contrary, their competition reflected their shared appeal to similar audiences. Lee's own Mormon mission work confirms this insight: Methodists were frequent targets of Lee's evangelism on behalf of his new faith. Not only did Lee claim to have cast out devils at Methodist class meetings, he also boasted that he had converted enough residents in the Methodist stronghold of central Tennessee (the same area where Alexander Fancher was born) to plant a new Mormon congregation. ${ }^{14}$

In the formative years before the Civil War, Mormons and Methodists thus had much in common. Like the Methodists, Latter-day Saints were recent arrivals who had moved often. They, too, focused on building the

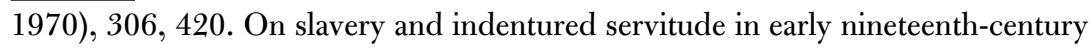
Illinois, especially Kaskaskia and its environs, see M. Scott Heerman, "In a State of Slavery: Black Servitude in Illinois," Early American Studies 14 (Winter 2016), 114-39.

12. Lee, Mormonism Unveiled, 51-53.

13. Jan Shipps, Mormonism: The Story of a New Religious Tradition (Urbana, IL, 1985), 51-65.

14. Lee, Mormonism Unveiled, 127-28. 
Kingdom of God that, according to Mormon (and Methodist) belief, would precipitate the Millennium. Methodists converted to Mormonism in greater numbers than did any other faith. Church leaders, including Brigham Young, had roots in Methodism. Brigham's brother Lorenzo Dow Young (named after the renowned Methodist itinerant, Lorenzo Dow) exemplified the power of Methodism in the Young family before their conversion to Mormonism, and the importance of family ties in both traditions. The overlap has seemed obvious to historians of Methodism and Mormonism in the early twenty-first century, who have noted that converts to Mormonism adopted ecclesiastical structures from Methodists in a classic form of the mimesis that characterized early nineteenth-century pluralism. We extend the insight deeper into the two religious cultures and the dynamism of expansion westward. ${ }^{15}$

The ill will between the two fast-growing faiths was as real as their common ground. A Methodist minister rejected the emerging prophet Joseph Smith, proclaiming that he had not had a genuine vision of God. Instead, the reverend declared that "it was all of the devil, that there was no such thing as visions or revelations in these days, that all such things had ceased with the apostles and that there would never be any more of them." This minister might well have felt the sting of competition for converts among the ordinary folk to whom both Methodist and Mormon evangelists appealed. The mutual mistrust between the two groups, therefore, was predictable, the product of their similarities and their shared targets in the mission field. ${ }^{16}$

15. See, e.g., Fournal of Discourses of President Brigham Young, His Counselors, and Other Church Leaders, 26 vols. (1854-1886; repr. Los Angeles, 1956), 3: 42-47, Oct. 6, 1855. Stephen C. Taysom, Shakers, Mormons, and Religious Worlds: Conflicting Visions, Contested Boundaries (Bloomington, IN, 2010), 169-95; Paul H. Peterson, "The Mormon Reformation of 1856-1857: The Rhetoric and the Reality," fournal of Mormon History 15 (Jan. 1989), 59-87, esp. 61-62; Thomas G. Alexander, "Wilford Woodruff and the Mormon Reformation of 1855-1857," Dialogue 25 (Summer 1992), 25-38; Gene Sessions, ed., Mormon Thunder: A Documentary History of Jedediah Morgan Grant (Urbana, IL, 1982), 244-6; Nathan O. Hatch, The Democratization of American Christianity (New Haven, CT, 1989), 20-22; Richard L. Bushman, foseph Smith: Rough Stone Rolling (New York, 2005), 40-41; Christopher C. Jones, "We Latter-day Saints Are Methodists': The Influence of Methodism on Early Mormon Religiosity," MA thesis, Brigham Young University, 2009.

16. Dean C. Jessee, ed., The Papers of Foseph Smith: Autobiographical and Historical Writings, 2 vols. (Salt Lake City, UT, 1989), 1: 273. 
In this sense, the religious violence that marked Mountain Meadows was more intimate than we have recognized. As the historian Natalie Zemon Davis described religious riots in sixteenth-century France, such local cataclysms "had a connection in time, place and form with the life of worship." Neighbors turned against those whose practices had become strange, but whose heritage was shared. In early national America, violence, religious ritual, and justifications for bloodshed traveled with those whose repeated migrations led them west. And like the religious riots studied by Davis, the conflagration between Mormon and Methodist was fueled by deep relationships among folk of similar and overlapping histories. Their religious practice fed and in turn was fueled by quotidian assurance of God's plan for history, especially based in Exodus and the conquest of Canaan. "The Bible," noted religion scholars Susan Juster and Linda Gregerson, "was the foremost travel guide in early modern European history." In our study, this role for the Bible extended beyond the Age of Discovery, into the early republic and the antebellum era, brought westward by ordinary migrants like Fancher and Lee, who carried their divine mandate with them as they moved with their kinfolk. ${ }^{17}$

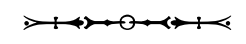

Like the Fanchers, the Methodist preachers and converts attacked so assiduously by Lee in the 1830s came primarily from small towns and rural backgrounds, often with artisanal skills as well as experience in agriculture and animal husbandry. Fancher, for example, bought and traded horses, and raised pigs and cattle. He was especially known as a skillful butcher. Such adaptable country people shared heritages of mobility, and were invested in geographic expansion in an age that celebrated self-improvement and experimentation. All along the constantly shifting demographic periphery, settlers encountered haggard Methodist itinerants, whose lives were spent on horseback in search of souls to bring to Christ. Physically and spiritually, both itinerant and convert

17. Natalie Zemon Davis, "The Rites of Violence: Religious Riot in SixteenthCentury France," Past \& Present 59 (May 1973), 51-91, esp. 90. Susan Juster and Linda Gregerson, "Introduction," in Empires of God: Religious Encounters in the Early Modern Atlantic, ed. Linda Gregerson and Susan Juster (Philadelphia, 2011), 1 . 
were adventurous and mobile people. Methodism grounded such rootlessness through searing conversions among common folk, and provided them not only with hope of eternal salvation, but a movable social and spiritual network of believers. ${ }^{18}$

Most of Alexander Fancher's history was lost when all records of the wagon train and any books or letters were apparently taken and most likely destroyed in the massacre. This is one legacy of the fatal convergence that is our ending point, a challenge to historians to engage the past in what one scholar called "a space of productive attention to the scene of loss." Part of such attention is a broad, even panoramic view of religious history, migration, and conflict. Equally important, our reading of the archive and its silences self-consciously engages with what is plausible, logical, chronological-and at the same time incomplete and partial. This process produces a "history written with and against the archive," to use Saidiya Hartman's phrase. What we have pieced together suggests a man who was not a simple victim, but one whose movements and their apparent motivations situate him in community and family. The patterns we can discern, therefore, yield a figure whose precise outlines are indistinct but whose life (and death) connect him interstitially to religious change and expansion in the antebellum era. Both Lee and Fancher brought violent histories with them to Mountain Meadows, grounded in religious belief that sustained conquest and subjugation. (See Figure 2.) ${ }^{19}$

We have no documents that reflect Fancher's faith in his own words. Yet we know that his family was part of this upwelling of Methodist fervor along the shifting frontier. The Fanchers and many others valorized westward expansion as a religious mandate for white settlers and practiced routine violence against Native Americans. Like other Methodists of the old Southwest and Midwest who became Jacksonian Democrats, Alexander Fancher fought (and likely killed) Indians. And like the

18. Githens, "The Fancher Family"; Fancher, Alexander Fancher, 36-40.

19. Lisa Lowe, "The Intimacies of Four Continents," in Haunted by Empire: Geographies of Intimacy in North American History, ed. Ann Laura Stoler (Durham, NC, 2006), 191-212, esp. 208. For the usefulness of panorama in piecing together motivations and events to provide clues where gaps in primary sources make a narrative elusive, see Linda Gordon, The Great Arizona Orphan Abduction (Cambridge, MA, 1999), x. Hartman, "Venus in Two Acts," Small Axe 12 (June 2008), 1-14, esp. 12. 


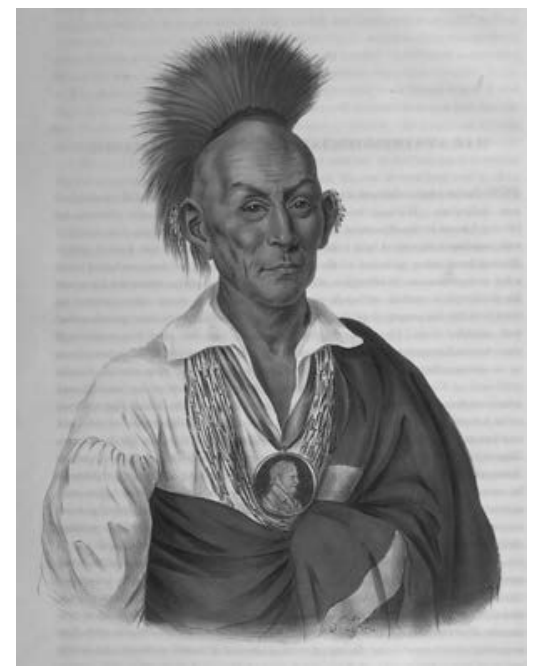

Figure 2: Black Hawk, Sauk and Fox Chief, was "toured" around the country after his capture and became a central figure in campaign for forcible removal of southeastern and Midwestern tribes. Both Alexander Fancher and John D. Lee participated in the Battle of Bad Axe in 1832, and may well have met each other then. History of the Indian Tribes of North America (Philadelphia, 1872), 2:29. Courtesy of the University of Pennsylvania.

one in the Book of Genesis to which Methodists often compared it, therefore, the "American Canaan" also had inconvenient and religiously expendable inhabitants. So certain were they of God's blessing on their enterprise that many Methodists were blinded to the possibility that their destruction of Native peoples might itself be anything other than an exercise in Christian virtue. Especially in the vast migration across the continent that built the American empire in antebellum America, Methodists rationalized even pre-emptive violence against Native Americans as the inevitable cost of ensuring that land "which but a few years past was only inhabited by the tawny savage ... [now] blossometh as the rose." ${ }^{" 20}$

In the Black Hawk War of 1832, Fancher (and Lee) first served in

20. Wigger, "Fighting Bees," 88-95, 100-107; Hatch, The Democratization of American Christianity, 67-113; Fisher, Albion's Seed, 703-708. For the language of Canaan, see Christine Leigh Heyrman, Southern Cross: The Beginnings of the Bible Belt (New York, 1998), xx, 4-9; Eran Shalev, American Zion: The Old Testament as a Political Text from the Revolution to the Civil War (New Haven, CT, 2013), 84-117. On the connection between imperial expansion and religious vir- 
military action against Natives. Fancher's father and uncle both were sergeants, and Fancher himself served as a corporal, ordered to prevent desperate Natives from escaping from an island in the Mississippi River where they were trapped. The conflict ended with the slaughter of hundreds of Sauk and Fox warriors, as well as many women and children who were mowed down by a steam-powered gunboat (ironically named "Warrior") as they tried to flee. ${ }^{21}$

By the 1830s, Methodist leaders had developed distinctive explanations for such carnage. Fancher's biographer, himself a descendant of several Mountain Meadows Massacre victims, follows that pattern. Chief Black Hawk, he claims, "waged war against white settlers" by violating a treaty that ceded all land east of the Mississippi. The Indian chief broke this deal, so the story went, when he and more than a thousand followers attempted to resettle ceded lands. (Black Hawk argued that the 1804 treaty was invalid, because it had not been duly authorized by tribal leaders.) Of those who moved with him, fewer than half survived, and Black Hawk himself was imprisoned and "toured" around eastern cities, a celebratory process that allowed white easterners to rationalize the slaughter. As easterners feted the Indian chief, they were persuaded that Black Hawk was a noble but tragically outmoded figure, respected by his captors and honored with statues and plaques. ${ }^{22}$

Frontier militiamen such as Lee and Fancher helped turn the Black Hawk War into a justification for Indian removal. The war and the subsequent parade of prisoners allowed the Fancher family's friend and hero, the storied Indian fighter and now U.S. President Andrew Jackson, to pressure the remaining tribes in the old Northwest and across the Southeast into crushing treaty cessions and eventually subjected them to forcible removal in the 1830s. At the same time that Sauk prisoners enacted the drama of submission in the East, ambitious and entrepreneurial families like the Fanchers drove ever deeper into newly opened areas, convinced that the new Canaan, God's great bounty, was theirs by right. Religious growth and geographic expansion thus traveled hand in

tue, see Paul Stevens, "Spenser and the End of the British Empire," in Empires of God, ed. Gregerson and Juster, 248; Williams, Religion and Violence, 109.

21. Fancher, Alexander Fancher, 23-26; Lloyd H. Efflandt, Lincoln and the Black Hawk War (Rock Island, IL, 1991), 27.

22. Kerry A. Trask, Black Hawk: The Battle for the Heart of America (New York, 2006), 298-308. Fancher, Alexander Fancher, 23-27, quotation 24. 
glove, making westward migration an act of religious significance, a "high destiny," according to an 1834 edition of the Methodist magazine the Western Christian Advocate. Methodist missionary Thomas Hinde explained the formula: Christian pioneers in the West, he said, subdued Native infidels and conquered the land for "the kingdom of the blessed Jesus." This tunnel vision was central to the exercise of violent removal in the service of the coming reign of the great peacemaker. ${ }^{23}$

Alexander Fancher embodied this ideal of mobility in the interest of religious growth. But Fancher and other entrepreneurial Methodist men also used their new-found religious power to establish themselves at the head of family dynasties. As they led their dependents in successive moves westward, they assumed and augmented their command over kith and kin. Fancher and his family moved many times-first to Illinois, then Missouri, and by the mid-1840s, to the Arkansas Ozarks. Most likely, he squatted there, a practice that many frontiersmen believed was both justified and economical (they could squat with impunity on thousands of acres, or pay $\$ 1.50$ per acre in hard cash for a much smaller portion). Fancher also worshipped there, although church life was informal in the rural counties where the Fancher family settled. According to one descendant, Fancher was a regular at Methodist worship services held in the house of his uncle, James Fancher. Such home-based religious life was another feature that Fancher shared with Lee-whose family worshipped together in Harmony, where their houses functioned as chapels as well as homes. As head of the household, therefore, Lee held power over worship as well as family life, ingredients of patriarchy in Utah as well as Arkansas. Without question, however, James Fancher, not

23. John W. Hall, Uncommon Defense: Indian Allies in the Black Hawk War (Cambridge MA, 2009), 206-64; Fancher, Alexander Fancher, 10-15; Williams, Religion and Violence, 109-10, quotation 113 (quoting Methodist Minutes, in William Warren Sweet, The Methodists: A Collection of Source Materials [Chicago, 1946], 4: 60); Methodist Magazine (Sept. 1822), 359; Conrad Cherry, God's New Israel: Religious Interpretations of American Destiny (Chapel Hill, NC, 1998); Isaiah 35: 1 (King James Version); "Western Life," Western Christian Advocate, May 9, 1834, 5, cited in Williams, Religion and Violence, 114; Hinde, "Account of the Rise and Progress of the Work of God in the Western Country," 395-96, 434-39. On the frequent use of such Old Testament imagery, see Heyrman, Southern Cross, 3-26. On Christian grace as a key rationale for expansion and ingredient in the cultural invisibility of the violence associated with imperialism, see Gregerson and Juster, "Introduction," 14. 
Alexander, was the family patriarch in Arkansas, in a society that took patriarchy seriously. The move to California at the head of a large company and with detailed plans for growth would install Alexander Fancher at the head of his own patriarchal realm. ${ }^{24}$

As older, local constraints vanished under wagon wheels, the power of the patriarch increased commensurately. And while we cannot know the details of how Fancher interacted with his company, the trail itself was a powerful lesson in the powers of men over women, especially a train captain. The long journey rewarded confidence, physical and psychological aggression, preening, bravado, and often brutality. One observer described the pressure on men, whose "pugnacious and belligerent propensities" were stoked by the demands of constant vigilance, as well as the "perpetual vexations and hardships" that the trail inevitably entailed. The role of the hunt, at which Fancher was evidently greatly skilled, was also intensified on the trail, as the search for game (especially antelope or buffalo) was not only designed to provide food for dependents, but also to demonstrate mastery over the new land through bloodletting. Reduced to essentials, the conquest of new land through migration also reinforced mastery over those who depended on the unflinching confidence and leadership provided by men like Fancher. ${ }^{25}$

Here, too, Methodism played a key role. In westward migration, the power of the Spirit traveled with the company of believers, sustaining their determination to plant the seeds that would create the Kingdom at the end of the trail. According to reports from other trains, Fancher's party stopped regularly for worship on Sunday. Immersion in rituals of

24. Eventually, Fancher acquired title, but only to forty acres, perhaps as payment for his participation as a local militiaman in suppressing a bloody local feud between two families in 1849. Fancher, Alexander Fancher, 46-48, 53-57; W. B. Flippin, The History of Marion County (np, 1876), http://www.argenweb.net/ marion/stories/marion-co-ar-wb-flippin-history.html; Donald J. Pisani, "The Squatter and Natural Law in Nineteenth-Century America," Agricultural History 81 (Fall 2007), 443-63. On family life and patriarchy within Mormonism, see B. Carmon Hardy, "Lords of Creation: Polygamy, the Abrahamic Household, and Mormon Patriarchy," Fournal of Mormon History 20 (Spring 1994), 119-52.

25. Edwyn Bryant, What I Saw in California (New York, 1849), 66, quoted in John Mack Faragher, Women and Men on the Overland Trail, 2nd ed. (1979; repr. New Haven, CT, 2001), 97; Catherine L. Albanese, "Savage, Sinner, and Saved: Davy Crockett, Camp Meetings, and the Wild Frontier," American Quarterly 33 (Winter 1981), 482-501, esp. 489. 
meaning and devotion, which reminded migrants that they partook in this larger conquest of the land for Jesus, gave context and purpose to the voyage. It united the company by shifting their gaze upward to the heavens and into sacred space and time. According to family legend, Fancher knew that simmering resentments could divide companies, and regular worship helped smooth frayed nerves on the journey. Weekly worship also inscribed the power dynamics of the frontier, of course. The expansion of Christian peoples into and across the continent, led by a man whose roots in family and faith supported this incursion, replicated other migrations led by patriarchs, especially the biblical Abraham. ${ }^{26}$

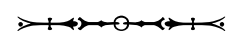

John D. Lee was also a patriarch. His journey to power, like Fancher's, was conditioned by his faith as much as his mobility and personal ambition. Like other Mormons, Lee endured the derision of outsiders-the Saints, especially their Prophet Joseph Smith, were infamous. They were

26. On reports from other trains, see Fanny Stenhouse, "Tell It All": The Story of a Life's Experience in Mormonism (Hartford, CT, 1874), 325; Bagley, Blood of the Prophets, 68. On the role of ritual and family cohesion, see Heyrman, Southern Cross, 256-57; A. Gregory Schneider argues that domestication and elevation of the importance of family within Methodism subverted "traditional patriarchy," a social hierarchy he views as in sharp contrast to market principles, The Way of the Cross Leads Home: The Domestication of American Methodism (Bloomington, IN, 1993), 2-10, 59-77. Recent scholarship has challenged this binary division. See, e.g., Walter Johnson, River of Dark Dreams: Slavery and Empire in the Cotton Kingdom (Cambridge, MA, 2013); Edward E. Baptist, The Half Has Never Been Told: Slavery and the Making of American Capitalism (New York, 2014). Looked at in light of both secondary scholarship and the research presented here, patriarchy and the market were inscribed together in the lives of early national Methodists in the Old Southwest and in the antebellum diaspora. It is fair to say, however, that the patriarchy exercised by migrant leaders such as Fancher was not identical to lowland slaveholders in the Old South. Instead, it was a new iteration, based on a shifting frontier and mobile faith. In this sense, the patriarchy we find among Methodist migrants was remade and expanded to suit new circumstances and ways of exercising power. These patriarchs were sustained in lived religion, as the trail separated migrants from their former homes, and invested their captain with power and responsibility. As the legal scholar Reva Siegel has argued, "preservationthrough-transformation" was endemic in status-based relations across the nineteenth century. "The Rule of Love': Wife Beating as Prerogative and Privacy," Yale Law fournal 105 (June 1996), 2118-70, esp. 2119. 
persecuted, ridiculed, and despised; often, they moved to survive. From New York, to Ohio, to Missouri (where Lee found them in 1838), to Illinois, the Saints fled their many opponents. Migration was also a religious command within Mormonism. Converts were told to "gather" wherever the community of Saints was found. This repeated gathering in turn generated fear in surrounding settlements, which fed on stories and rumors of earlier conflagrations among other communities. The pressure of repeated migration also played out in Mormon life, dividing the faithful and generating even greater need for powerful men to patrol the boundaries of community. Soon after Lee gathered in Far West, Missouri, he became a member of the "Danites," a secretive organization reputedly dedicated to hunting down both anti-Mormons and apostates. In 1843, Lee joined the "Police Force of Nauvoo, Illinois," created by the Prophet to protect him from outside opponents and in particular from betrayal from within. In 1844, the Prophet's fears were realized; first he was betrayed by dissidents within the community of Saints and then murdered by a mob of anti-Mormons. Mistrust of local government was so deep among the Saints that the prosecution of Smith's accused murderers failed in part because Mormons were afraid to appear as witnesses. ${ }^{27}$

Their faith was less than twenty years old when Mormons suffered the martyrdom of their Prophet. Smith's murder eventually led many of his followers westward in 1847. By then, stories of anti-Mormon persecution were so imprinted on Mormon identity that even temple ceremonies called for avenging "the blood of the prophets." In their new Kingdom in the tops of the mountains, a more powerful church emerged under the second president and prophet Brigham Young and those to whom he delegated substantial local authority. ${ }^{28}$

27. D. Michael Quinn, "Culture of Violence in Joseph Smith's Mormonism," Sunstone (Oct. 2011), 16-88, 21-24, 27; History of the Church of Fesus Christ of Latter-day Saints, 8 vols. (Salt Lake City, UT, 1912), 6: 152 ("we have a fudas in our midst"; emphasis in original); Dallin H. Oaks and Marvin S. Hill, Carthage Conspiracy: The Trial of the Accused Assassins of Foseph Smith (Urbana, IL, 1976); Davis Bitton, The Martyrdom Remembered: A One-Hundred-Fifty Year Perspective on the Assassination of Joseph Smith (Salt Lake City, UT, 1994). History of the Church of Fesus Christ of Latter-Day Saints, 6: 149.

28. David John Beurger, "The Development of the Mormon Temple Endowment Ceremony," Dialogue 20 (Winter 1987), 33-76, esp. 55; Shipps, Mormonism, 41-65. 


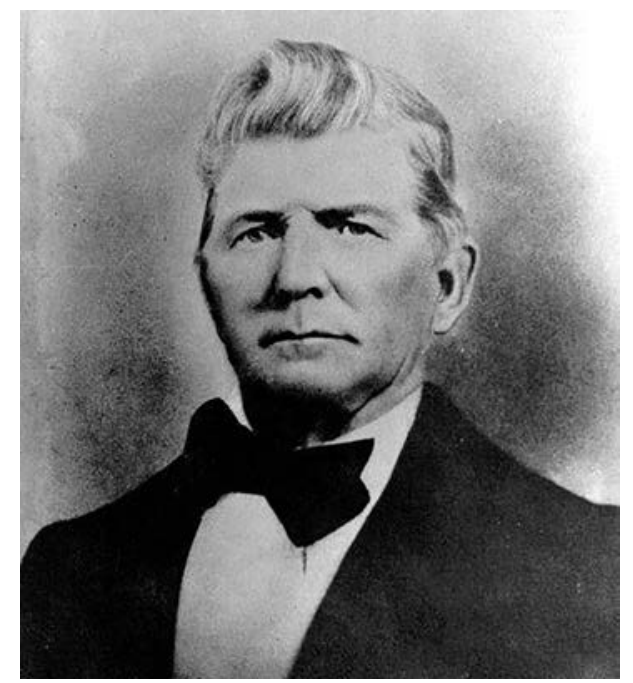

Figure 3: This photograph of John D. Lee in middle age was likely taken at about the same time as the Mountain Meadows Massacre in 1857. No image of Fancher survives, as all records of the Fancher train have disappeared, likely destroyed by the perpetrators. Lee and Alexander Fancher were both 45 years old then-both had moved many times and become powerful patriarchs. Courtesy of Southern Utah University.

President Young sent his followers far and wide around the Great Basin. The Mormons gathered in their nascent Kingdom of God, that is, but the diaspora into which they were funneled meant that they were separated geographically and socially, even if related spiritually. Young chose a battle-tested coterie of Saints for southern Utah, one of the harshest corners of Zion. Many had known Joseph Smith and trekked across the plains with Young. John D. Lee was their leader, and the trusted emissary and confidant of President Young. (See Figure 3.) When he founded the first Mormon settlement at Harmony in 1851, Lee served as the local bishop, probate judge, commander of the private militia known as the Nauvoo Legion, and Indian agent for the region. $\mathrm{He}$ directed mining and milling projects, and became a prosperous farmer. This was the patrimony Lee built in the hardscrabble environment known incongruously as "Utah's Dixie" and that he sought to protect against Alexander Fancher and his ilk. ${ }^{29}$

29. Of sixty-eight militiamen who participated in the massacre, all came across the plains, many were at Nauvoo (almost 50 percent), some at Kirtland and/or Missouri (more than 15 percent). Debra Marsh, Study of Baptismal Dates of Iron 
Yet Lee and his extended family, who believed that they were unique, nonetheless shared many attributes with other American pioneers. They lived at the margins, practiced their faith at home, and struggled to subdue the land. Like other westward moving migrants, the Saints found that the land was already claimed physically and spiritually by Native Americans. Mormons also brought slaves west with them. And once they arrived in the Great Basin, Mormons followed what was now a familiar American religious template; they, too, subdued their new Zion just as the Israelites spread across Canaan-through conquest and settlement. The Mountain Meadows Massacre is part of that subjugation story. ${ }^{30}$

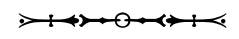

The road to California was the last of Alexander Fancher's many migrations; his murder was bound up with the great hopes and tensions unleashed by a growing America. Fancher's westward movement illustrates the geographic specificity as well as the power and complexity of this history, and the ways that religious beliefs in God's blessing supported national expansion and personal ambition. By the mid-1850s, Fancher had completed at least one (and most likely two) cattle drives from Arkansas to California. He was also known as an expert judge of horseflesh; on this trip, he brought a beautiful stallion, rumored to be the finest horse ever to have crossed the plains. Fancher also planned carefully for social order on the trail, grounded in a regular schedule of religious observance. The train was assured of familiar Methodist worship, conducted by circuit rider Pleasant Basham. Otherwise, experienced captains knew, discord could overwhelm even a well-organized

County Militia/Mountain Meadows Massacre, June 9, 2011 (unpublished ms.); Janet Burton Seegmiller, A History of Iron County: Community Above Self (Parowan, UT, 1998), 45-64; Robert Glass Cleland and Junita Brooks, eds., A Mormon Chronicle: The Diaries of Fohn D. Lee, 1848-1876, 2 vols. (San Marino, CA, 1955), 1: 133-36; Brooks, Fohn Doyle Lee, 169-81. By the late 1850s, it was rare for Mormon communities not to include Scandinavian and/or British recent converts. Contrast the Iron County population, for example, with Manti, where large numbers of Danes had been settled in the early 1850s. Kathryn M. Daynes, More Wives Than One: Transformation of the Mormon Marriage System, 18401910 (Urbana, IL, 2001), 117-18, 129-30.

30. Jack Beller, "Negro Slaves in Utah," Utah Historical Quarterly 2 (Oct. 1929), 122-26. Slaveholders included the first mayor of Salt Lake, a member of the Quorum of Twelve Apostles, and the future Utah representative in Congress. 
group on the long drive westward. Their services were conducted in the open air, as Methodists brought the Kingdom with them as they traveled. $^{31}$

Traditionally, historians have explained increasing conflict between white Americans over expansion in terms of the pressures of slavery and greed for land on national cohesion. Yet Fancher's life and death also highlight the importance of religion to the narrative. It is not that slavery was less a lightning rod than we have assumed, but more that expansion, slavery, Native displacement, and religion were synthetically woven together. Each brought distinct ingredients to the cauldron. The challenges of religious pluralism and the connection of religion to slavery (and other forms of bondage) were illustrated not only by Methodism and Mormonism, but also in the ways both expanded westward. Fancher, to cite one example, could plan to sell beef in California because the secularization of the Catholic Missions there included expropriation of more than a million acres that had been set aside for some 15,000 Native ranchers. Mormons also brought slaves to California in the 1850s. This shared dedication to slavery and subjugation of Native peoples became another step in the progression westward for the New Canaan. ${ }^{32}$

Newell G. Bringhurst, "The Mormons and Slavery: A Closer Look," Pacific Historical Review 50 (Aug. 1981), 329-38, esp. 332.

31. On the genealogy of Pleasant Basham, including birth, marriage, and death, as well as service to Methodist Church, see genealogical website Ancestry.com, http://search.ancestry.com/cgi_bin/sse.dll?gl=ROOT_CATEGORY\&rank = 1\& new $=1 \& \mathrm{MSAV}=0 \& \mathrm{~ms} \mathrm{~T}=1 \& \mathrm{gss}=$ angs-c\&gsfn $=$ pleasant $\&$ gsln $=$ basham $\&$ mswpn_ftp $=$ arkansas $\&$ msbdy $=1813 \&$ uidh $=$ q0c. Telephone confirmation with Lynnmarie Fancher, Nov. 18, 2014 (explaining that Basham was assigned to evangelize the "Indian Line" that began west of Arkansas, but that he left the train before it reached Salt Lake). Basham was buried in Arkansas in 1864, making him the most likely preacher to have accompanied the train. Many Methodists records in Arkansas were destroyed during the Civil War; thus we cannot confirm whether Basham rode with the train. Basham, also born in central Tennessee, was said to have accompanied the train as far as Cedar City. Some accounts report that Methodist minister Pleasant Tackitt (sometimes spelled "Tackett") and his family were among the travelers, and that the Reverend Tackitt conducted services while on the trail. Others challenge the claim, pointing out that Tackitt had a nephew of the same name, and that the uncle moved from Arkansas to Texas in the early 1850s and survived well into the 1880s. "Pleasant Tackett," Texas State Historical Association, http://www.tshaonline.org/handbook/online/articles/fta01.

32. Fancher, Alexander Fancher, 84. John C. Pinheiro, Missionaries of Republicanism: A Religious History of the Mexican-American War (New York, 2014); 
There is no scholarly treatment of the Arkansas migrants that connects their migration to broader American religious and social history to make up for the loss of records in the massacre. Equally important, we have no women's diaries or letters to supplement what would likely have been terse entries in the logbook, nor do we have the train's constitution, a common feature of such well-organized migrations to California. We know of the dread many white women felt of Native Americans, and the stories they told of horrendous torture inflicted on victims. We also know that many migrating women distrusted the Latter-day Saints, including one who refused to let a Mormon doctor deliver her child. But the specific experiences of this train, especially but not only during the siege that lasted several days before their murder, have disappeared. ${ }^{33}$

Yet the kinfolk and descendants of the victims have become avid family historians, recovering as much as they can in an effort to restore the past and seek justice. In the nineteenth century, they collected and published the recollections of the surviving children. They have formed associations (some of which feud with others), made family trees, blogged, and even published a book on Alexander Fancher with a vanity press. All of these researchers express their outrage as they attempt to retell and celebrate the lives of Fancher and his company. Most claim that Brigham Young was the mastermind behind the massacre, and they blame the fanaticism of Mormons generally for the slaughter. Their research is substantially based on the memories of the survivors, reports from migrants who traversed the area soon after the massacre occurred, and family legends and stories about those who were murdered. These are lay histories, powerful because they

Priscilla McArthur, Arkansas in the Gold Rush (Little Rock, AR, 1986); Hubert Howe Bancroft, History of California, 7 vols. (San Francisco, 1885), 3: 339-62, 6: 529-81. On Mormon slaves in California, see Dolores Hayden, "Biddy Mason's Los Angeles, 1856-1891," California History 68 (Fall 1989), 86-99, esp. 86; Delilah L. Beasley, The Negro Trail Blazers of California (Los Angeles, 1919), 88-90, 109-13. On the ways westward expansion produced both freedom and subjugation, see Ari Kelman, A Misplaced Massacre: Struggling over the Memory of Sand Creek (Cambridge, MA, 2013), 278-79.

33. For women's accounts, see Lilian Schlissel, Women's Diaries of the Westward fourney (New York, 1982); Kenneth L. Holmes, ed., Covered Wagon Women: Diaries and Letters from the Western Trails, 1854-1860, vol. 7 (Lincoln, $\mathrm{NE}, 1987)$. For the story of the woman who refused medical care in Salt Lake City, and a broader discussion of wagon train constitutions, see John Phillip Reid, Law for the Elephant: Property and Social Behavior on the Overland Trail (San Marino, CA, 1980), 1-25, 154. 
are popular efforts to recover what was lost to Fancher family history. Equally important, they are significant because they are the only surviving traces of many victims' lives. ${ }^{34}$

The Fancher descendants are thus participants in a form of vernacular history, cultivated across time and in conversation. In this sense, Fancher family history reverberates with fine work in the history of slavery, challenging us to recognize that our engagement with this past is itself an effort to overcome an imposed silence. These stories and the vocabulary of outrage that accompanies them are evaluations of a violent past. Historians who tread on such ground risk romanticizing their subjects and/or alienating those who have worked to retain shards of a past that has been substantially erased. Yet not to do the work of reassemblage, which in our case blends cautious use of survivors' memories and family legends with wide secondary reading, would be to miss insight into Mountain Meadows. This would, we believe, unduly privilege empiricism over constructive

34. See, e.g., Mountain Meadows Association, http://www.mtn-meadows -assoc.com/; Mountain Meadows Monument Foundation, http://mmmf.org/, http://1857massacre.com/index.htm; Richard Fancher Society, http://1857mass acre.com/MMM/richard_fancher_society.htm; Githens, "The Fancher Family"; Alison C. Wallner and Paul B. Fancher, The Fancher Family Origins (2003), http://freepages.genealogy.rootsweb.ancestry.com/ wallner/fanshawe.htm; Burr Fancher, Alexander Fancher, 117, 119-21, passim. The authors of this article have also spoken with J. K. (Terry) Fancher, president of the Mountain Meadows Association, as well as Alison Wallner and Lynnmarie Fancher, co-authors of a forthcoming study on the massacre (no title, publisher). These Fancher family historians have been joined by a small coterie of Mormon scholars, activists, and journalists, who have attempted to understand the victims' part in the story of the massacre. To date, no scholarly work has emerged from this group. The unpublished reflections of historian Lawrence W. Coates include "President Hinckley's Dedication: Behind the Scenes"; "Healing Bitterness, 1859-1991"; and "Leadership Bumps Challenge the Mountain Meadows Association [May 2013]" (all in possession of the authors). When excavation at the site uncovered the bones of victims in 1999, Coates and his wife were charged with carrying the remains to Brigham Young University for examination. He described the experience as deeply moving: "They became human beings in my mind and I could picture them and feel them as though they were there. I remember as vividly as if it were yesterday when I carried those four boxes of bones into the hotel and knelt in prayer at the side of the bed and asked Heavenly Father to help and protect us. I can't put into words how I felt-it was sobering spiritual experience to have that kind of communication" (notes of telephone conversation with Lawrence Coates, Aug. 1, 2013). Although beyond the scope of this essay, Coates's mystical encounter illustrates the ongoing reverberations of the massacre in religious life. 
engagement. Such memories and legends are complex materials. But they also yield critical balance to analysis of the massacre, helping among other things to establish the striking overlap in basic doctrines of faith, personal ambition, and life experience of Alexander Fancher and John D. Lee. ${ }^{35}$

Working with such materials requires a sense of their value to the victims' families, as well as their usefulness and limits for historians. For one thing, these stories and legends illustrate the vital force of family networks in religious life and westward expansion. They are also clearly partisan-yet even in their evident advocacy, they reveal the many ways that Mountain Meadows reverberated in Arkansas and beyond. Historians of westward expansion know well the difficulty of working on migrants; they have long advised that we should listen to the women whose letters, memoirs, and account books reveal a more nuanced picture of the trail. Family histories, of course, are largely the province of women, and such is the case here. Focusing on family religion and networks of kin among Methodists as well as Mormons, moreover, permits a comparison of perpetrator and victim that highlights the many and unexpected shared elements of daily religious practice among common folk, including an emphasis on the importance of spiritual recordkeeping in diaries, memoirs, church records, and correspondence. Not only the loss of life, but the loss of such written records is among the many bitter injuries inflicted at Mountain Meadows. Like Mormons, Methodists were dedicated record-keepers, correspondents, and diarists, chronicling their progress and movements. ${ }^{36}$

35. The language of theft characterizes much of such engagement with a violent and destructive past. Edward E. Baptist, "Stol' and Fetched Here': Enslaved Migration, Slave Narratives, and Vernacular History," in New Studies in the History of American Slavery, ed. Edward E. Baptist and Stephanie M. H. Camp (Athens, GA, 2006), 243-74; Michael A. Gomez, Exchanging Our Country Marks: The Transformation of African Identities in the Colonial and Antebellum South (Chapel Hill, NC, 1998), 199-207; Anne C. Bailey, African Voices of the of the Atlantic Slave Trade, Beyond the Silence and the Shame (Boston, 2005), 1-27. On the difficulties and opportunities of working as a stranger among those who have a present stake in the memory and portrayal of the past, see Saidiya Hartman, Lose Your Mother: A fourney along the Atlantic Slave Route (New York, 2007), 76-83. For a recent debate on the value of a more self-reflective critical stance, see Brian Connolly, "Against Accumulation," 719: The fournal of Nineteenth-Century Americanists 2 (Spring 2014), 172-87; Nathan Perl-Rosenthal, "Comment: Generational Turns," American Historical Review 117 (June 2012), 804-13.

36. For the importance of women's histories, see Julie Roy Jeffrey, Frontier Women: "Civilizing" the West? 1840-1880 (New York, 1998). Patricia Nelson 
It is crucial not to confuse the slaughter of the train and the destruction of records with the centuries-long invisibility imposed by the slave trade, of course. The Fancher family were white southerners. Some studies even claim that the Fanchers brought slaves in their train, a possible but unproven assertion, and we cannot establish that Fancher himself owned slaves in Arkansas or elsewhere. Nonetheless, we can be confident that he supported slavery. Fancher died in 1857, but even after the Civil War his family preserved the patterns of patriarchy. Before the war, the great embrace and spread of slaveholding among white male Methodists lifted the Fancher family fortunes as they became slaveholders in Arkansas. Fancher moved along the frontier of the upper South across his lifetime and was the product of a slaveholding society. Methodists in Arkansas voted overwhelming to join the Methodist Episcopal Church, South when the denomination divided over slavery in 1845 , led by a preacher who, like the Fanchers, had come from Tennessee. Alexander's uncle James, a slaveholder and substantial landholder in Osage, Arkansas, hosted the Methodist services that Fancher attended. James lost most of his property and livestock during the Civil War, when Union soldiers looted his farm, burning all buildings and stealing everything they could find, according to a statement that is still in possession of his descendants. James's brother Gray Bynum Fancher, a staunch proslavery Democrat, sent six sons to fight for the Confederacy. ${ }^{37}$

Limerick, The Legacy of Conquest: The Unbroken Past of the American West (New York, 1987); Linda Peavy and Ursula Smith, Pioneer Women: The Lives of Women on the Frontier (Norman, OK, 1998). On Mormon recordkeeping, see Book of Doctrine and Covenants (Independence, MO, 1960), section 47 (Mar. 8, 1831), 114. Hempton, Methodism, 60-68. Francis Asbury, first superintendent of the American Methodists, accumulated almost no property in his forty years of service in North America. Yet he was so scrupulous in preserving documents related to his many travels as a missionary that his letters and journals fill three volumes. John H. Wigger, American Saint: Francis Asbury and the Methodists (New York, 2009), 9-12; Elmer T. Clark, J. Manning Potts, and Jacob S. Payton, eds., The Fournal and Letters of Francis Asbury, 3 vols. (Nashville, TN, 1958).

37. For the claim that the train included slaves, see Bagley, Blood of the Prophets, 65. Affidavits given by relatives do not mention slaves. See Roger V. Logan, Jr., "New Light on the Mountain Meadows Caravan," Utah Historical Quarterly 60 (Summer 1992), 224-37. Orville W. Taylor, Negro Slavery in Arkansas (Fayetteville, AR, 2000); Gary Battershell, "The Socioeconomic Role of Slavery in the Arkansas Upcountry," Arkansas Historical Quarterly 58 (Spring 1999), 45-60. See also the online Encyclopedia of Arkansas, a project of the Butler Center for 
The sticky legacy of slavery emerges from the lips of a Fancher family historian. Mattie Ma Wilkins, born in Georgia in 1849, married Alexander's nephew in Arkansas in 1873. She was attended by "Aunt Margaret," a mulatto woman who had been "welcomed into [the Fancher home] as part of their family" after she had been "abandoned" as a child by her parents. For Aunt Margaret, more than sixty years of "hardscrabble" work followed this welcome, as she kept house for Mattie Ma and her children, carded wool, spun thread, and knitted socks and mittens. Margaret was remembered as late as 1931, trailing a few steps behind her mistress after an evening of storytelling. ${ }^{38}$

Mattie Ma's stories were gruesome. She had one topic: the Mountain

Arkansas Studies at the Central Arkansas Library System (CALS) in Little Rock, Arkansas, http://www.encyclopediaofarkansas.net/encyclopedia/entry-detail.aspx ?entryID = 1275. Nancy Britton, Two Centuries of Methodism in Arkansas, 18002000 (Little Rock, AR, 2000), 38-65. On the MECS preacher Augustus R. Winfield and his Tennessee origins, see Norma S. Arnold, "Early Churches and Preachers," Clark County Historical fournal 4 (Winter 1979-1980), 44-46. On James Fancher, see Githens, "The Fancher Family." On the genealogy of Gray Bynum Fancher, including birth, marriage, children, and death, see records at Geni.com, http://www.geni.com/people/Gray-Bynum-Fancher/600000000080 2860512.

38. Fancher, Alexander Fancher, xiii-xv. The label aunt or uncle, of course, was a common method of describing a black slave or underpaid servant. This pattern lasted well into the twentieth century, and was especially potent in the 1920s and 30s. M. M. Manring, Slave in a Box: The Strange Career of Aunt Femima (Charlottesville, VA, 1998); Ulrich Bonnell Phillips, American Negro Slavery, A Survey of the Supply, Employment, and Control of Negro Labor as Determined by the Plantation Regime (New York, 1918). According to Burr Fancher, "the busy Aunt Margaret found time to prove up on a homestead of 160 acres on upper Sweden Creek," and acquired title to the property. Alexander Fancher, xiv, 227n5. Family legend also says that several former slaves remained with Elizabeth Fancher (James Fancher's daughter-in-law) after the Civil War, including Mariah, a "beloved" enslaved woman who had been bequeathed to Elizabeth by her father, and is believed to have been Elizabeth's half-sister. On James Fancher's genealogy, including birth, marriage, and death, as well as copy of his statement about the value of his property destroyed by Union troops, and his last will and testament, see records at Geni.com, http://www.geni.com/people/James-Fancher/60000 00000141704795. Photograph of grave of Mariah Fancher, which describes her as born a slave to the Sneed family in 1841 who lived with Elizabeth Sneed Fancher until her death in 1901, is at http://www.findagrave.com/cgi-bin/fg.cgi? page $=\operatorname{gr} \&$ GRid $=8592716$. 


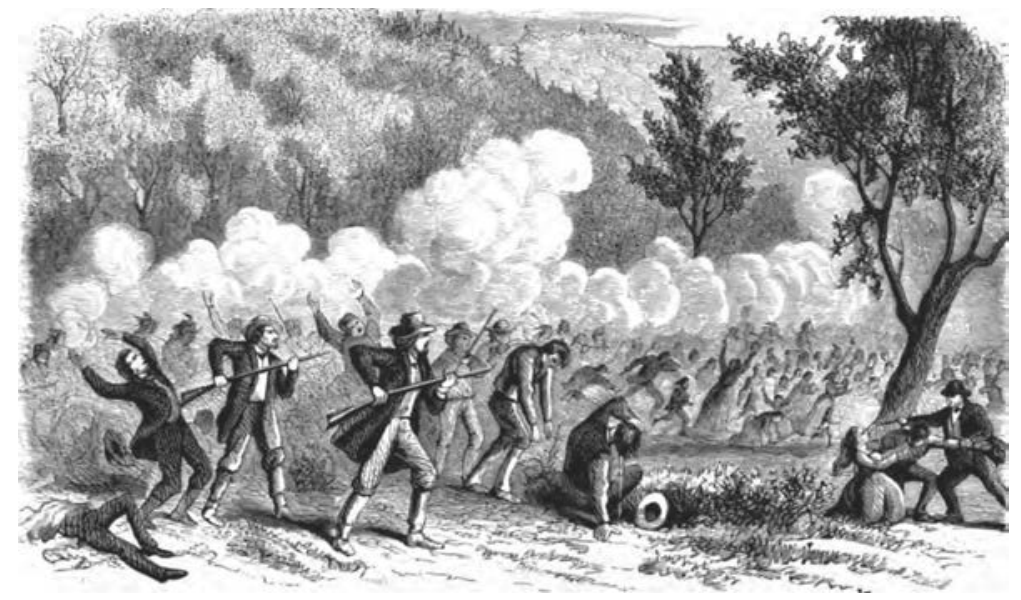

Figure 4: John D. Lee and other Mormons blamed local Paiutes for the massacre. But outsiders quickly challenged this exculpatory story. And a former leading member of the Church published a stinging account of Mountain Meadows, which included an illustration that showed white men shooting helpless migrants. T. B. H. Stenhouse, The Rocky Mountain Saints: A Full and Complete History of the Mormons (London, 1873), 465. Courtesy of the University of Pennsylvania.

Meadows Massacre. Seventy-five years after the event, Mattie Ma would tell the tale at family reunions, spinning out details about the Fanchers in the 1850s, the wagon train, its leader, and the innocent victims. She wanted her listeners to know their history. Fancher children sat in a circle around Mattie Ma as she spoke for hours, building over several nights to the dramatic and bloody climax. Do not forgive the Mormons, she said at the end, because Brigham Young was the real villain; his followers never admitted Young's responsibility for the infamous massacre. "Christian forgiveness," Mattie Ma declared, was reserved for those who admit their sins. Instead, the Mormons were fanatics, a breed apart from the Fanchers and their kind. In such stories, the Methodist Fancher clan cultivated the memory of a great and violent wrong and called for vengeance against the blood-letters in an annual ritual of remembrance, much as Mormon temple ritual spoke of avenging the blood of the prophets. (See Figure 4.) ${ }^{39}$

Mattie Ma Fancher was outraged at the murder of Alexander Fancher,

39. Fancher, Alexander Fancher, 175. 
but she elided the fact that her own family stole the lives of enslaved people-arguably including Aunt Margaret. Of course, slavery came in many guises and affected many peoples in antebellum America. Southern Utah, where the massacre occurred, was a crossroad for Native slave traders. John D. Lee engaged in a growing trade there among Mormons: the purchase of Indian children. He bought the first, a boy he named Lemuel, in the early winter of 1851 just after arriving in southern Utah. Other leading Mormons sent to settle the area also bought children, and Lee made his biggest purchase in a single week in 1858-four girls, two of whom he apparently traded to other local families. The purchase and sale of children, and Mormon claims that they "saved" these Native children and brought them into their extended families, have long been the subject of both religious and social debate. The kidnapping of Native children was a vibrant business by the 1850 s, in California, Utah, and other southwestern territories. Many such traders were themselves Native, but others were white. ${ }^{40}$

Scholars now regularly use the word "slavery" to describe the condition of these young captives. Traditionally, Mormons called the relationship "adoption," explaining that they purchased young Natives to save them from abuse, starvation, and even torture. The economics of the trade in Utah were obvious-Native groups could demand guns, ammunition, and horses, playing on Mormons' sympathies for the plight of kidnapped children and their desire to assimilate them into the Mormon faith. In California, where the Fancher train was headed, the need for farm and domestic workers was dire, especially after the eviction of Natives from former Mission lands. There, as in Utah, young children were a prime target for kidnappers, Native and white. Traders would often kill adults and older children, saving toddlers and those up to about age seven to be sold to farmers and their wives. In Utah as in California, these children were not slaves for life, nor were they free.

40. Brooks, fohn Doyle Lee, 164, 238; Stephen V. Hoak, "And Who Shall Have the Children? The Indian Slave Trade in the Southern Great Basin, 18001865," Nevada Historical Society Quarterly 41 (Spring 1998), 3-25; James F. Brooks, Captives \& Cousins: Slavery, Kinship and Community in the Southwest Borderlands (Chapel Hill, NC, 2002), 327-60; Andres Resendez, The Other Slavery: The Uncovered Story of Indian Enslavement in America (New York, 2016), 266-77. 
Instead, they were subject to indenture in both jurisdictions, bound to labor for their foster families to repay the cost of their own purchase. ${ }^{41}$

In both California and Utah, traders already kidnapped and sold children when Euro Americans arrived. The presence of new settlers in land-rich and labor-poor regions, however, increased the profits of the practice. The invigorated slave trade made less warlike tribes, such as the Southern Paiutes, whose homelands surrounded the region settled by John D. Lee, especially vulnerable. At least one local Mormon evidently became a trader in Indian children. When Mormon Apostle George A. Smith visited Parowan, he advised the man on exactly how much he should pay for a child. This man was later seen carrying one small child, and leading a mule with two other children strapped on its back, as he traveled north. And in an eerie echo of Indian slave-trading patterns, the perpetrators of the Mountain Meadows Massacre spared seventeen children under the age of eight, who were "adopted" into local homes. The value of children, spiritually as well as economically, traveled deep into the Mormon community of southern Utah. ${ }^{42}$

41. Michael Magliari, "Free State Slavery: Bound Indian Labor and Slave Trafficking in California's Sacramento Valley, 1850-1864," Pacific Historical Review 81 (May 2012), 155-92; Stacey L. Smith, Freedom's Frontier: California and the Struggle over Unfree Labor, Emancipation, and Reconstruction (Chapel Hill, NC, 2013), 109-40. "An Act for the Further Relief of Indian Slaves and Prisoners [1852]," Acts, Resolutions, and Memorials of the Legislative Aseembly of the Territory of Utah (Salt Lake, 1866), 87-88; "An Act for the Government and Protection of Indians [1850]," Statutes of California (San Jose, CA, 1850), 408-10.

42. Sondra Jones, "Redeeming' the Indian: The Enslavement of Indian Children in New Mexico and Utah," Utah Historical Quarterly 67 (Summer 1999), 223-26; Journal of George Albert Smith (1817-1875), Mar. 1851 (cited in Jones, 233). The Book of Mormon described Native Americans as Lamanites, a remnant of the "House of Israel," and thus the Saints had a special obligation to reach out to these biblical peoples. Yet violent conflict and expropriation of Indian lands were common in early territorial Utah, as elsewhere in the southwest and around the globe in the nineteenth century. John C. Weaver, The Great Land Rush and the Making of the Modern World, 1650-1900 (Montreal, 2003), 341-44. Moreover, Mormons found that the Southern Paiutes did not match the scriptural portrait of Lamanites. While touring southern Utah in 1851, Brigham Young dismissed them as "descendants of the old Gadianton Robers [sic]," murderers and thieves in the Book of Mormon. Journal History, Church of Jesus Christ of Latter-day Saints, Historical Department, May 16, 1851, 1, in W. Paul Reeve, "As Ugly as Evil' and 'as Wicked as Hell': Gadianton Robbers and the Legend Process Among the Mormons," Fournal of Mormon History 27 (Fall 2001), 125- 


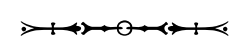

Like Mormons, Methodist migrants fed into and deepened bondage in frontier societies already marked by trade in human flesh. Fancher evidently chose the route to southern California for multiple reasons, including its southern sympathies. For one thing, his brother John was already established in Tulare, and Alexander had scouted out likely grounds there for his own ranch, where he planned to raise cattle to sell to hungry gold miners. Members of the wagon train from surrounding areas in Arkansas represented extensive kin networks created by intermarriage among those who had come to the Ozarks from similar religious and social backgrounds. Many of the men had militia experience, often in armed conflict with Indians. Some dozen major family groups joined the train. Surely, they were spurred in part by the sense of entitlement that their religious convictions and self-interest told them justified the move west. No less than the Mormons, theirs was a kingdom built on conquest and subjugation. ${ }^{43}$

In the 1850 s, southern and central California was suited to people like the Fanchers. Politically and religiously, these areas were closely allied to the upper South. Proslavery advocates there hoped to divide California in two, admitting the southern portion as a slave state, a plan that had the overwhelming support of residents from Los Angeles to Fresno. Slavery already had divided Methodists in the mid-1840s, and the bitter

49, esp. 139. The Gadiantons brought temptation to the people of God. Brigham Young said that their demonic survivors (in the form of Paiutes) were "ready to make us covetous, if they can; they are ready to lead astray every man and woman that wishes to be a Latter-day Saint." Fournal of Discourses 8 (Jan. 20, 1861); Harmony Fournal, Dec. 18, 1858, 3. Walker, et al., Massacre at Mountain Meadows, 216-17; Bagley, Blood of the Prophets, 154, 158-60. These children were later returned to Arkansas, thanks primarily to the efforts of Dr. Jacob Forney and the Arkansas legislature. "Children of the Massacre," St. Louis Post Dispatch (MO), July 1893, http://www.mtn-meadows-assoc.com/st_louis_post-dispatch .htm\#Tryphena\%20Fancher.

43. According to the records, John Fancher registered a cattle brand in Tulare in 1852. Fancher, Alexander Fancher, 93, 237n16; W. B. Flippin, "The Tutt and Everett War in Marion County," Arkansas Historical Quarterly 17 (Summer 1958), 155-63; http://www.argenweb.net/marion/stories/marion-co-ar-tutt -everett-war-1.html. 
schism reinforced a particularly southern and deeply expansionist Methodism. This new religious order generated great spiritual energy and conviction that was based in the religious defense of bondage and confinement. Biblical truths (versus northern infidelity), they claimed, was at the heart of their faith and their society. By the late 1850s, southern Methodists accused northerners of betrayal and persecution, especially in imposing their political (rather than genuinely spiritual) views on those who had a constitutional right to own slaves. ${ }^{44}$

From the earliest days of the great expansion of U.S. territory that brought Utah as well as California into the American empire, therefore, religious divides tracked the settlers who streamed into spaces they imagined were ripe for the taking. The Fancher train, like other organized companies, traveled in carefully constructed groups, made up of religious and biological kin that created communities of common belief and family strategy. Through migration, the Fanchers and other Methodists celebrated kinship, cementing the connections between religious and family growth.

Once they arrived in California, southern Methodists built churches early_in 1852 (near Tulare) and 1854 in Los Nietos, currently just outside Los Angeles. As in Arkansas, Methodist migrants in California, including the Fanchers, were firmly allied to the southern branch of their divided church. ${ }^{45}$

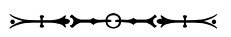

In multiple ways and many places, therefore, slavery appeared in the earliest days of antebellum Kingdoms of God, both Methodist and Mormon. Even though slavery had been sharply criticized by the founders of both traditions, their successors adapted. When Methodist preachers

44. Smith, Freedom's Frontier, 47-79; Kevin Waite, "California's Forgotten Proslavery Past," History News Network 6, July 2014, http://hnn.us/article/ 156215. Richard J. Carwardine, "Methodists, Politics, and the Coming of the American Civil War," in Methodism and the Shaping of American Culture, ed. Hatch and Wigger, 331-40; John Nelson Norwood, The Schism in the Methodist Episcopal Church 1844: A Study of Slavery and Ecclesiastical Politics (1923; repr. Philadelphia, 1976); Donald G. Mathews, Slavery and Methodism: A Chapter in American Morality (Princeton, NJ, 1965); Britton, Two Centuries of Methodism, 56-57; Mark A. Noll, The Civil War as a Theological Crisis (Chapel Hill, NC, 2006), 33-39.

45. Beverly McClung MacVicar, "Southern and Northern Methodism in Civil War California," California Historical Quarterly 40 (Dec. 1961), 327-42. 
attacked slavery in the late eighteenth and early nineteenth centuries, they encountered "stony defiance" from the laity in the old Southwest. Soon, the hunger for souls overwhelmed conscience. Methodist conversions grew by leaps and bounds among folk like the Fanchers once slavery was no longer a stumbling block. Mormons followed a different but related path. Joseph Smith quickly dissociated his church from abolitionism when Mormons in Missouri were accused of antislavery in the late 1830s. But he lashed out against slaveholding in the early 1840s. In 1852, however, Mormon territorial legislators, acting at the urging of Brigham Young, legalized slavery in Utah, then the only western territory to do so. The standard explanation for this about-face has been Young's desire to accommodate a dozen or so slaveholders in Utah, and even to court additional southerners. Looking deeper, an appeal to southern principles made great sense for the Mormons, who in 1852 publicly announced another peculiar domestic institution-polygamy. ${ }^{46}$

John D. Lee was an enthusiastic practitioner of patriarchal marriage, as polygamy was called by the Saints. His nineteen wives bore him sixtyseven children. The law of the Abrahamic family, according to Mormon doctrine, granted worthy men the power to rule justly and command obedience. So vested was Lee in the patriarchal powers of the polygamous husband, that he dictated to one of his wives: "she must adhere to his council $[s i c]$ for he was her Husband, Bro., Father, President \& Saviour." There was a direct relationship between such wifely submission to the will of her "lord," and statements such as that of Chief Justice Thomas Ruffin of the North Carolina Supreme Court that in a slaveholding society, "the power of the master must be absolute, to render the submission of the slave perfect." ${ }^{947}$

46. Heyrman, Southern Cross, 93 (quotation); Mathews, Slavery and Methodism, 177-211. "General Assembly," Latter day Saints Messenger and Advocate, Aug. 1835, 1: 161-64 (later published in Doctrine and Covenants, 134: 12); Joseph Smith, Jr., General Smith's Views of the Powers and Policy of the Government of the United States (Nauvoo, IL, 1844), 3; W. Paul Reeve, Religion of a Different Color: Race and the Mormon Struggle for Whiteness (New York, 2015), 148-52; John G. Turner, Brigham Young, Pioneer Prophet (Cambridge, MA, 2012), 223-28. New Mexico Territory legalized slavery in 1859. "An Act to provide for the protection of property in Slaves in this Terriotry," Laws of the Territory of New Mexico (Santa Fe, NM, 1859), 64-80.

47. Brooks, fohn Doyle Lee, 379-84. Cleland and Brooks, eds., A Mormon Chronicle, 1: 10 (quoted in Hardy, "Lords of Creation," 137); State v. Mann, 13 N.C. 263 (1829). 
Perfection of human society, in both Mormon marital theory and Methodist proslavery, depended upon male authority. Mormon patriarchs held the "keys of power"; the Abrahamic family played a similar role in the religious defense of slavery. Where Mormons pointed to Genesis 16 for the (polygamous) Abrahamic "law of the family" in the story of Hagar, southern proslavery apologists stressed the same chapter for the point that the godly patriarch Abraham owned slaves. In 1850 as debates raged over the Fugitive Slave Law, proslavery biblical scholar Moses Stuart argued that northerners should not presume to judge their southern brethren because according to Mosaic law both were tribes of Israel. Abraham was also the leader of a migration, of course, the first great builder in the Kingdom of God, and in antebellum America common men understood themselves as the heirs of Abraham. When they met in Mountain Meadows, therefore, both Fancher and Lee were powerful and experienced men-American exemplars of a renegotiated and biblically justified patriarchy. ${ }^{48}$

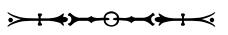

Lee profited from the slaughter. In November 1857, Lee billed the federal government $\$ 2,200$, saying that the aggression of "Capt. Fancher" had unleashed Indian barbarity and caused considerable expense; in early 1858 , Lee expanded his patrimony by taking his fifteenth wife. He also acquired a magnificent stallion, clearly Fancher's prize horse, valued at $\$ 2,000$. Lee's wives soon appeared dressed in the clothes and jewelry of dead women; cattle, wagons, carriages, and other spoils found their way into the hands of Lee and local Mormons. ${ }^{49}$

The massacre has been debated ever since. Brigham Young and other

48. Parley P. Pratt, Marriage and Morals in Utah (Liverpool, 1856), 2, 4; "Hagar and Ishmael," Fuvenile Instructor, Oct. 15, 1868, 1; Moses Stuart, Conscience and Constitution (Boston, 1850), 30-32; Mark A. Noll, "The Bible and Slavery," in Religion and the American Civil War, ed. Randall M. Miller, Harry S. Stout, and Charles Reagan Wilson (New York, 1998), 43-50; William E. Hull, "Learning the Lessons of Slavery," Christian Ethics Today 43 (Feb. 2003), 5-9.

49. Letter from John D. Lee to Brigham Young, Nov. 20, 1857, http://law2 .umkc.edu/faculty/projects/ftrials/mountainmeadows/leelettertoby.html; Seegmiller, History of Iron County, 269; Daniel S. Macfarlane (1892), in Mountain Meadows Massacre: The Andrew Fenson and David H. Morris Collections, ed. Richard E. Turley, Jr. and Ronald W. Walker (Provo, UT, 2009), 119; Anna Jean Backus, Mountain Meadows Witness: The Life and Times of Bishop Philip Klingensmith (Spokane, WA, 1995), 155-58. The day after the massacre, Mormon participants 
Mormon leaders quickly learned the truth, although they never made it public. But after the Civil War Mormons were subjected to extraordinary outside pressure for their practice of polygamy and the massacre of the Fancher train. Non-Mormons argued that Mountain Meadows proved Mormon polygamists were murderous tyrants hiding behind a fraud they called religion. This story played well in the non-Mormon press, firmly connecting plural marriage to Mountain Meadows, and vice versa. Mormons finally offered up sacrifices to the ravening crowd in the $1870 \mathrm{~s}$-at the same time, they further cultivated their own sense of victimhood. Outsiders did not bother to understand the divine mandate for polygamy, the Saints rightly argued. ${ }^{50}$

Recognizing the overlap between polygamy and violence in outsiders' view of the Saints allows us to see how deeply anti-Mormonism drew on the connections between faith and bloodshed. Vengeance also played a central role in Mormon interpretations of Mountain Meadows. In 1859, federal investigators found bones and even pieces of human hair still in the field, and built a cairn to mark the spot. (See Figure 5.) When Brigham Young visited the site in 1861, he reacted differently. "Vengeance is mine, saith the Lord, and I will repay it" was written on a wooden cross atop the piled stones. Young retorted that the sign should read: "Vengeance is mine and I have taken a little." Young then lifted his arm: "[I]n five minutes there wasn't one stone left upon another," said one follower. "He didn't have to tell us what he wanted done. We understood." Outside the faith, however, repeated denials by the church supported charges that the church and its president must be guilty because they lied about what really happened. ${ }^{51}$

Slowly, it became undeniable that outsiders' suspicions were justified. Federal investigators hounded Mormon leaders in Salt Lake, but eventually focused on John D. Lee. The church's decision to blame Lee (and only him) was part of a new strategy, which reflected the ways that popular opinion condemned the massacre. In 1870, Lee was excommunicated

met at Mountain Meadows where their leaders charged them to say that the Indians did it. Some accounts say they swore a blood oath to kill anyone who talked. Bagley, Blood of the Prophets, 215-16; David L. Bigler and Will Bagley, eds., Innocent Blood: Essential Narratives of the Mountain Meadows Massacre (Norman, OK, 2008), 165.

50. See, e.g., T. B. H. Stenhouse, The Rocky Mountain Saints: A Full and Complete History of the Mormons (London, 1873), 424-58.

51. Ibid., 453; Young quoted in Woodruff Journal, May 25, 1861, 182 for vengeance; Dudley Leavitt quoted in ibid., 183, 183n16. 


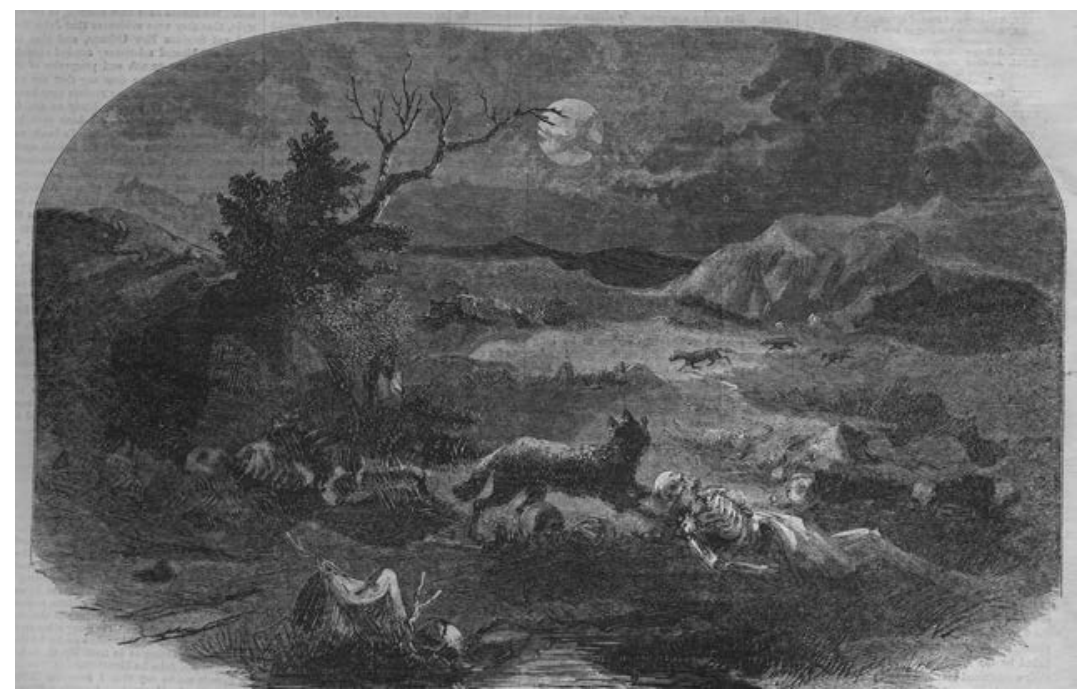

Figure 5: The popular magazine Harper's Weekly published a report of the Mountain Meadows Massacre in 1859 that blamed Mormon polygamists directly for murder, rape, and theft, and featured this imagined scene of the massacre's grisly aftermath. Harper's Weekly, Aug. 13, 1859. Courtesy of the Library Company of Philadelphia.

from the LDS Church "for Committing a great sin." Church leaders thereby deflected attention onto Lee. His guilt was so obvious to all concerned, said one contemporary observer, that it would have been "impossible [for church leaders] to acquit him without assuming a part of the responsibility themselves." According to Lee family legend, Young declared that Lee's sins would be "visited upon the heads of [his] children until the third and fourth generation," a familiar Old Testament curse, revived in Mormon teaching. In 1874, Lee and eight other Mormon men were indicted by a grand jury, but only Lee stood trial. Lee's first trial ended in a hung jury, but he was convicted the following year and executed by firing squad at Mountain Meadows in 1877. In some senses, the Mormon strategy worked: Attention to the massacre receded once Lee was buried. The Fancher family still told the story of Alexander Fancher and the train he led. Their calls for justice went unheeded, however. ${ }^{52}$

52. For Lee's excommunication, see Brooks, Mountain Meadows Massacre, 188-210, 219-20. Joseph Smith used the curse, especially when speaking of the punishment of his enemies. Doctrine and Covenants, 98: 37, 103: 25-26. On the 


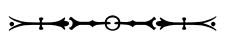

At Mountain Meadows, competing visions of the American Kingdom of God met head on. The frontier functioned as a pressure cooker, in this sense, not a safety valve. Fancher and Lee both had traveled far in their lives, coming from the Old Southwest across the plains. They viewed themselves as endowed by God with a mandate to move across the American landscape and to invest it with religious meaning. This mandate was also enmeshed in family, whether blood relatives (Fancher) or religious kin (Lee). Both men had constructed family patrimonies and webs of patronage. They brought their extended families with them as they moved, increasing their command over dependents as they moved further away from their starting points. On the road to California, far from Salt Lake, far from Carroll County, Arkansas, the Mormon Trail brought together this pair of leaders. There, both men's habit of command and sense of self rested on faith and decades of experience. Their convergence, finally, was fatal to both men.

It was a blood-filled and terrifying spectacle. The confrontation lasted for days, as those inside the encircled train grew desperate as their water, food, and ammunition were exhausted. Finally, when they agreed to walk away from all their possessions with Mormon escorts, the real slaughter began. According to one young girl who was among the seventeen children spared, "the sight of blood sent them [white Mormons and their Indian companions] into a fanatical frenzy. One huge white kept shouting "For Jehovah." "John D. Lee reported that another of the perpetrators declared as he shot wounded men: "O Lord, my God, receive their spirits, it is for thy Kingdom that I do this." In the half hour that it took to complete the massacre of 120 adults and older children, most were shot in the head and some were bludgeoned to death. ${ }^{53}$

Lee family legend, see Bagley, Blood of the Prophets, 355; Edna Lee Brimhall, comp., "Gleanings Concerning John D. Lee," Church History Library, Church of Jesus Christ of Latter-day Saints, Salt Lake City. On Young's many legal troubles and strategies in the $1870 \mathrm{~s}$, including the John D. Lee trial, see Turner, Brigham Young, 385-407.

53. "Mary Elizabeth (Baker) Terry Account of the Mountain Meadows Massacre," http://www.mtn-meadows-assoc.com/bakerterry.htm; Lee, Mormonism Unveiled, 241; Shannon A. Novak, House of Mourning: A Biocultural History of the Mountain Meadows Massacre (Salt Lake City, UT, 2008), 161-74. 


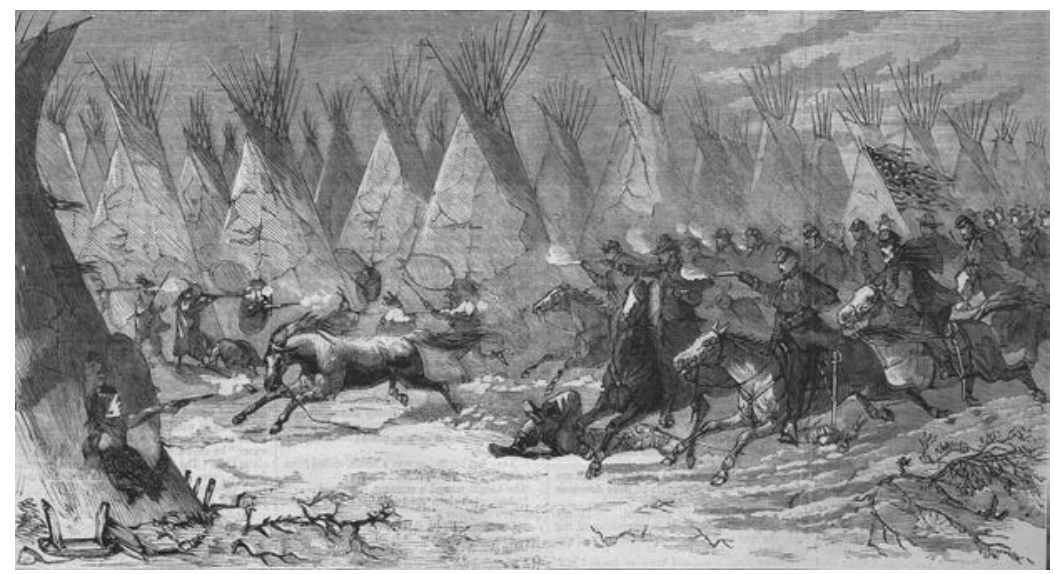

Figure 6: Union colonel and Methodist clergyman John Chivington led the Sand Creek Massacre, which resulted in the slaughter of as many as 163 Cheyenne Indians in 1864. He defended his actions as necessary to prepare the American Canaan for the Kingdom of God that would be built there. Harper's Weekly, Nov. 22, 1868. Courtesy of the Library Company of Philadelphia.

Yet they shared so much. Bringing religion back in gives us a richer picture of the event and its connection to other massacres of the era. The contest between Fancher and Lee turned on distinct but related claims to religious truth and to the territorial expression of their spiritual commitments. As they tacked westward, Mormons had been "driven" by opponents. The slaughter of unarmed Latter-day Saints (in Missouri, Illinois, and even Arkansas only a few months before the massacre) did not necessarily predict violence at Mountain Meadows, but it does make credible the claim that one could easily imagine Mormons as the victims of such a slaughter in 1857, rather than its perpetrators. Equally telling, the 1864 Sand Creek Massacre in eastern Colorado was led (and celebrated) by Colonel John Chivington, a Methodist minister who had turned down a Union chaplaincy early in the Civil War, and volunteered to fight instead. Explaining how and why he was proud of his (grossly exaggerated) claim that he and his men had slaughtered 500 Cheyenne Indians, Chivington drew on the biblical language of Canaan. The eradication of savages, he said, was essential to the protection of white settlers in the West. (See Figure 6.) As one recent study of the massacre described the colonel's life-long defense of his conduct: "He and his 
men, Chivington contended, had served as the shock troops of expansion, beginning an American revival on the frontier. ${ }^{954}$

Mountain Meadows did not bring Mormon violence to a close, either. In April, 1866, in Circleville, Utah, Mormon settlers slaughtered some thirty Paiutes whom they had herded into a church meetinghouse. The Parowan militia, which advised bringing in all local Indians to ensure that they would not support Utes in an ongoing conflict, shared the Iron Military District of the Nauvoo Legion with the militia companies that had carried out the killing at Mountain Meadows. In the 1866 massacre, very young children were once again spared, and were "adopted" into local families. All old enough to "tell that tale" were murdered, some shot and others stunned by a blow to the head and then their throats were slit. And once again, the story was that a dispatch from Salt Lake arrived "too late." Mountain Meadows, apparently, had created a pattern that was followed later, right down to the identical exculpatory device: Church leaders were absolved of responsibility by the same method-a message urging moderation that appeared only after the slaughter was over. The reuse of the same excuse in this second massacre venue challenges the plausibility of both. ${ }^{55}$

54. "Massacre of Cheyenne Indians," Report of the Foint Committee on the Conduct of the War, at the Second Session, 38th Congress (Washington, DC, 1865), 108 (testimony of Lt. Col. J. M. Chivington); Kelman, A Misplaced Massacre, 17.

55. For the arrival of a message "too late" at Mountain Meadows, see Walker, et al., Massacre at Mountain Meadows, 226; for Circleville, see W. Paul Reeve, "Circleville Massacre, A Tragic Incident in the Black Hawk War," http://historyto go.utah.gov/utah_chapters/american_indians/circlevillemassacre.html; Carleton Culmsee, Utah's Black Hawk War (Logan, UT, 1973), 90-91; Jedediah Rogers, "Statement on History," in Remembering the Circleville Massacre, Utah Historical Quarterly 84 (Summer 2016), 265. The adoption and tale quotes are from Christian Larsen, "Biographical Sketch," Church History Library, cited in Albert Winkler, "The Circleville Massacre: A Brutal Event in Utah's Black Hawk War," Utah Historical Quarterly 55 (Winter 1987), 4-21, esp. 18. According to Native sources, three children escaped, a teenage girl and two small boys. One boy was sold by militia leader James Allred (brother of the local bishop), and became known by his adoptive name, David Monson. The girl was beaten to death in a particularly brutal fashion-she was swung by the heels and her head dashed repeatedly against a wagon wheel. The fate of the second boy is unknown. The story of the escaped children is told by a descendant of one of the perpetrators, who did not name his sources, apparently at their request. Phillip B. Gottfredson, "The Circleville Massacre in Utah," http://www.blackhawkproductions.com/circleville.htm. 
Much of the broader context treated here has lain just outside the gaze of work on Mountain Meadows. Historians of the massacre have given us admirable accounts of the immediate events, but little explanation of the ways that westward expansion and its deep religious roots linked the perpetrators to the victims. The narrow focus was established in the first monograph on the massacre. In 1950, almost a century after the Mountain Meadows Massacre, the historian Juanita Brooks (whose grandfather had participated in the slaughter) wrote the first scholarly treatment of the event. She concluded that Lee was a "scapegoat," offered up by Mormons to protect themselves and their church. Other than this one label for Lee, Brooks hardly mentioned religion in The Mountain Meadows Massacre. She wrote that Mormons were motivated not by their faith, but by fear of an approaching federal army. The army had not arrived when the massacre occurred, to be sure, but everyone knew it would be in Utah soon. She secularized the motives of the Mormon perpetrators, making them part of a political and military-but not religious-conflict. ${ }^{56}$

Brooks and her successors in Mormon history have also paid far more attention to the perpetrators than the victims of the massacre. Ironically, however, there is a similarity between Mormon historians who downplay the wider role of religion while not even attempting to understand that of the victims, and the Fancher descendants who argue that the religion of the perpetrators was wholly to blame, although they, too, do not reach across the religious divide to study the Mormon faith.

Recognizing the role of religion in westward expansion in antebellum America yields productive insights that connect Mountain Meadows with earlier religious templates for empire. The power of God's message to both Methodists and Mormons was unbounded, universal, and totalizing. Like those before them who were armed with such mandates, Mountain Meadows showed that religious justifications for empire entailed more than a template for dispossessing native inhabitants. The violence

56. Brooks, Fohn Doyle Lee; Brooks, The Mountain Meadows Massacre, 188 ("official sacrifice"); Klingensmith deposition, id., 238-42. For the official ritual that placed blame on a goat symbolically loaded with all the sins of the Israelites, see Leviticus, 16: 21-22. Religion scholar Rene Girard argued that this ceremony reduced tensions within the covenantal community, Violence and the Sacred, trans. Patrick Gregory (Baltimore, 1977), 251. Levi S. Peterson, Fuanita Brooks: Mormon Woman Historian (Salt Lake City, UT, 1988), 4-6; Jan Shipps, Foreword, Mountain Meadows Massacre, viii-ix. 
between competing European claimants to the Americas in the seventeenth and eighteenth centuries found new expression at Mountain Meadows, illustrating how aggression against other white migrants was part of the process of conquest. The militarism inherent in building the Kingdom of God in America justified offensive attacks against rivals, much as it justified earlier British attacks against Spain, France, and the Netherlands. The longer and deeper perspective shows that fatal convergence between white Christians was constructed on religious foundations that left lasting imprints in everyday lives and ambitions. John D. Lee and Alexander Fancher, restless and ambitious men, carried this legacy of violence and conquest in the name of God to southern Utah. There, it went ballistic. ${ }^{57}$

57. On religion and empire, see e.g., Carla Gardina Pestana, Protestant Empire: Religion and the Making of a British Atlantic World (Philadelphia, 2009); Travis Glasson, Mastering Christianity: Missionary Anglicanism and Slavery in the Atlantic World (New York, 2012); Alison Games, "Cohabitation, Suriname Style: English Inhabitants in Dutch Suriname after 1667," William and Mary Quarterly 72 (Apr. 2015), 195-242, esp. 195; Paul Stevens, Sola Gratia: English Literature and the Secular Ways of Grace (forthcoming); Juster, Sacred Violence; Emily Conroy-Krutz, Christian Imperialism: Converting the World in the Early American Republic (Ithaca, NY, 2015). 